
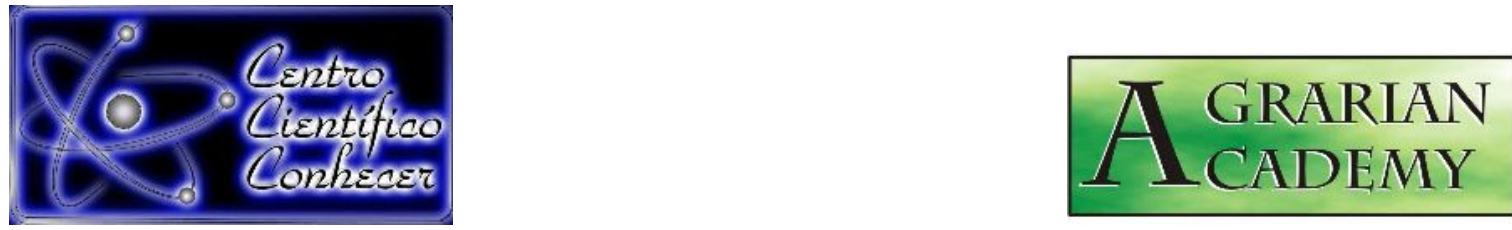

\title{
EFFICACY OF CHEMICAL AGENTS IN REDUCING FRUIT SET OF 'LETICIA' JAPANESE PLUMS
}
Jean Francisco Carminatti ${ }^{1}$, Lucas De Ross Marchioretto ${ }^{2}$, Poliana Francescatto ${ }^{3}$, Andrea De Rossi ${ }^{4}$, Leo Rufato ${ }^{5}$

${ }^{1}$ Master Student of Vegetal Production, State University of Santa Catarina (UDESC), Lages/SC, Brazil.

${ }^{2}$ Master Student of Vegetal Production, State University of Santa Catarina (UDESC), Lages/SC, Brazil, lucasdeross@hotmail.com

${ }^{3}$ Postdoctoral Associate at the Research Station of Temperate Climate Fruticulture, Embrapa Grape and Wine, Vacaria/RS, Brazil.

${ }^{4}$ Researcher at the Research Station of Temperate Climate Fruticulture, Embrapa Grape and Wine, Vacaria/RS, Brazil.

${ }^{5}$ Full Professor, State University of Santa Catarina (UDESC), Lages/SC, Brazil.

Recebido em: 19/11/2018 - Aprovado em: 14/12/2018 - Publicado em: 25/12/2018 DOI: 10.18677/Agrarian_Academy_2018B8

\begin{abstract}
Looking for improving 'Leticia' Japanese plums fruit quality and size, thinning of flowers and fruits have to be done early in the spring. Although, there are very few studies showing the effectiveness of chemical compounds that effectively promote thinning of stone fruits, especially for the Southern Brazilian conditions. Thus, the objective of this study was to investigate the effectiveness of several agents with potential to promote thinning at blooming or post blooming in 'Leticia' Japanese plums. To do so, in the cropping season of 2014/2015 the treatments abscisic acid, benzyladenine, benzyladenine + gibberellic $\operatorname{acid}_{4+7}$, ethephon, metamitron, vegetal oil, and calcium chloride were sprayed in 'Leticia' plums looking for evaluating the effects on the fruit set. The treatments ABA, benzyladenine, metamitron,

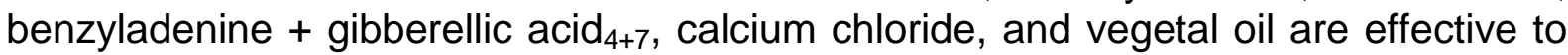
reduce fruit set of 'Leticia' plums in Southern Brazil.
\end{abstract}

KEYWORDS: thinning, flowering, Prunus salicina Lindl, abscission

\section{EFICÁCIA DE AGENTES QUÍMICOS NA REDUÇÃO DA FRUTIFICAÇÃO EFETIVA DE AMEIXEIRA 'LETICIA'}

\section{RESUMO}

Buscando melhorar a qualidade e o peso de frutos de ameixeira japonesa 'Leticia', o raleio de flores e frutos deve ocorrer no início da primavera. Entretanto, há muito poucos estudos demonstrando a eficácia de agentes químicos que efetivamente 
promovam raleio de frutos de caroço, especialmente nas condições climáticas da região sul do Brasil. Dessa forma, o objetivo desse estudo foi investigar a efetividade de diversos compostos com potencial de promover raleio de flores ou de frutos de ameixeira 'Leticia'. Para tal, na safra de 2014/2015, os tratamentos ácido abscísico, benziladenina, benziladenina + ácido giberélico ${ }_{4+7}$, etefom, metamitron, óleo vegetal, e cloreto de cálcio foram aplicados em ameixeiras 'Leticia' para avaliação dos efeitos dos tratamentos sobre a frutificação efetiva. Os tratamentos ácido abscísico, benziladenina, benziladenina + ácido giberélico ${ }_{4+7}$, metamitron, óleo vegetal e cloreto de cálcio reduziram a frutificação efetiva de ameixeira japonesa 'Leticia', no sul do Brasil.

PALAVRAS-CHAVE: raleio, floração, Prunus salicina Lindl, abscisão

\section{INTRODUCTION}

The size at harvest of temperate zone fruits, depends on the number of fruits that are growing simultaneously in the trees. For instance, in the apple crop it is necessary that up to $90 \%$ of the flowers abscise, so the fruits that are left can reach marketable size (LAKSO; GOFFINET, 2013). In addition, these authors reported that during early flowering the fruits have intense cell division rate along with intense shoot growth, creating a powerful competition between the shoots and fruits for assimilates; therefore, if the competition is eliminated early in the season there is a high potential for fruit growth. Another benefit from thinning early in the season is the removal of excess endogenous gibberellin from the growing fruitlets, which negatively interferes the flower bud induction, decreasing the amount of flowers and fruits in the following year (WEBSTER; SPENCER, 2000; EROGUL; SEN, 2015).

Usually, blossom thinners are composed of caustic substances (i.e. ammonium thiosulfate, urea, lime sulphur) that burns the stigmatic surface and inhibits pollen tube germination and consequently the fecundation, or an oily substance, which impedes the pollen grain adherence on the stigma or even blocks the pollen tube growth (FALLAHI; WILLEMSEN, 2002; FALLAHI; GREENE, 2010; McARTNEY et al., 2006; MARCHIORETTO et al., 2018; MARCHIORETTO et al., 2019). Although, both caustic compounds of oily compounds may have an indirect effect on the fruit abscission, as they damage the leaf tissue or create a barrier on the stomatas, decreasing leaf gas exchange rate and consequently the rate of assimilates production (LENAHAN; WHITING, 2006; McARTNEY et al., 2006). The main advantage of these agents is that they are not susceptible to weather conditions, as their effect are more direct (GREENE, COSTA, 2013).

Another group of chemical thinners are the plant growth regulators that are applied usually at post bloom aiming to fruitlet thinning. Growth regulators like benzyladenine, ethylene, and abscisic acid are the most commonly commercially available for perennial fruit trees (FALLAHI; GREENE, 2010; GIOVANAZ et al., 2015). Although, these compounds have a downside, which is the interference of weather conditions leading to unstable results. For instance, during spring, if the night and daytime temperatures are warmer and there is little solar radiation incidence (clouds), the trees will have a lower reserves status, making them more susceptible to thinning by these growth regulators; whereas, if the mean temperatures are cooler, and the solar radiation is more intense, then the trees will produce a greater amount of assimilates, making the effect of the growth regulators more difficult (GREENE, COSTA 2013). 
Stone fruit manual thinning may be quite expensive (FALLAHI; WILLEMSEN, 2002; MEITEI et al., 2013; PAVANELLO et al., 2018), especially because most producers are smallholder farmers with limited availability of resources. Although, pome fruits have the inconvenient of having a non-uniform flowering, with flowers at different phenological stages at blooming (FALLAHI, WILLENSEN, 2002). Therefore, new alternatives of thinners to be used at both bloom or post bloom have to be tested in conditions of southern Brazil. Thus, the objective of this study was to investigate the effectiveness of several agents with potential to promote thinning at blooming or post blooming in 'Leticia' Japanese plums.

\section{MATERIAL E METHODS}

The experiment was carried out in a commercial plum orchard located in the municipality of Jaquirana-RS, in the cropping season of 2014/2015. The orchard was trained in quad $V$ system with four main branches. The rootstock used was from peach seedlings, and the tree spacing was $2 \mathrm{~m}$ between trees and $6 \mathrm{~m}$ between rows. The orchard was cultivated with the Japanese plums of the cultivars Leticia and Santa Rosa, as pollinator. The treatments and the moment of application were performed as indicated in table 1. The experiment was conducted in a randomized complete block design with five replications of one tree for each treatment. The application of the treatments occurred on Sept. 5, 2014 with a motorized backpack sprayer. In the same day, four lateral branches in each plant were tagged with the total number of flowers. When the fruitlets had around $20 \mathrm{~mm}$ of diameter, they were counted again to calculate fruit set as the ratio of initial number of flowers by the final number of fruits multiplied per 100 to express the data as percentage. The data were subjected to analysis of variance (ANOVA) at $5 \%$ of probability, and in case of significance, the means were compared through the Scott-Knott test at $5 \%$ of probability using the software Sisvar v. 5.3 (FERREIRA, 2010).

TABLE 1. Commercial name, active ingredient, doses, and moment of application of the treatments in 'Leticia' plums.

\begin{tabular}{ccc}
\hline Treatments & $\begin{array}{c}\text { Dose of commercial } \\
\text { product }\end{array}$ & Moment of application \\
\hline Untreated Control & - & - \\
ABA & $500 \mathrm{mg} / \mathrm{L}$ & $\mathrm{FB}$ \\
ABA + Vegetal Oil & $500 \mathrm{mg} / \mathrm{L}+3 \%$ & $\mathrm{FB}$ \\
BA+GA $4+7$ & $1 \mathrm{ml} / \mathrm{L}$ & $\mathrm{FB}$ \\
BA+GA $4+7$ & $2 \mathrm{ml} / \mathrm{L}$ & $\mathrm{FB}$ \\
Calcium Chloride & $2 \%$ & $\mathrm{FB}$ \\
Vegetal Oil & $3 \%$ & $15 \mathrm{DAFB}$ \\
ABA & $250 \mathrm{mg} / \mathrm{L}$ & $15 \mathrm{DAFB}$ \\
ABA & $500 \mathrm{mg} / \mathrm{L}$ & $15 \mathrm{DAFB}$ \\
ABA + Metamitron & $150 \mathrm{mg} / \mathrm{L}+300 \mathrm{mg} / \mathrm{L}$ & $15 \mathrm{DAFB}$ \\
Benzyladenine & $15 \mathrm{~L} / \mathrm{ha}$ & $15 \mathrm{DAFB}$ \\
Ethephon & $2 \mathrm{ml} / \mathrm{L}$ & $15 \mathrm{DAFB}$ \\
Metamitron & $600 \mathrm{mg} / \mathrm{L}$ & $15 \mathrm{DAFB}$ \\
Metamitron & $500 \mathrm{mg} / \mathrm{L}$ &
\end{tabular}

Note: FB = Full Bloom; DAFB = Days After Full Bloom. 


\section{RESULTS AND DISCUSSION}

There was significant effect of the treatments on the thinning response of 'Leticia' plums (Table 2). Except abscisic acid (ABA) + metamitron and ethephon, both applied 15 days after full bloom (DAFB), all other treatments promoted flower/fruitlet abscission. The treatments calcium chloride at FB, benzyladenine at 15 DAFB, and vegetal oil at FB were the strongest thinners of this experiment, reducing 56,54 and $49 \%$, respectively, the numbers of fruits that set. The treatments ABA 500 $\mathrm{mg} / \mathrm{L}$ at full bloom (FB), ABA $500 \mathrm{mg} / \mathrm{L}$ at 15 DAFB, metamitron $500 \mathrm{mg} / \mathrm{L}$ at 15 DAFB, and benzyladenine + gibberellic acid $_{4+7}$ at FB were less effective to reduce fruit set than the latter treatments, but they presented a satisfactory response, reducing fruit set at a level of $45,39,32$ and $41 \%$, respectively. The treatments ABA $250 \mathrm{mg} / \mathrm{L}$ at $15 \mathrm{DAFB}, \mathrm{ABA} 500 \mathrm{mg} / \mathrm{L}$ + vegetal oil at FB, metamitron at $600 \mathrm{mg} / \mathrm{L}$ at 15 DAFB, and benzyladenine + gibberellic acid $_{4+7} 2 \mathrm{ml} / \mathrm{L}$ at $\mathrm{FB}$ had a milder response, reducing 22,25 , and $24 \%$, respectively the amount of fruits that set.

As the objective of chemical thinning is to reduce fruit set the most as possible to facilitate and reduce the costs of manual fruitlet thinning, the treatments that achieved this aim were the treatments calcium chloride and vegetal oil at FB, which have direct effect on preventing pollination, and the growth regulator benzyladenine sprayed at 15 DAFB. In addition, the treatments ABA $500 \mathrm{mg} / \mathrm{L}$ at FB, ABA $500 \mathrm{mg} / \mathrm{L}$ at $15 \mathrm{DAFB}$, metamitron $500 \mathrm{mg} / \mathrm{L}$ at $15 \mathrm{DAFB}$, and benzyladenine + gibberellic acid $_{4+7} 1 \mathrm{ml} / \mathrm{L}$ at $\mathrm{FB}$ can be considered as effective, based on the results they presented.

TABLE 2. Effect of different treatments of the fruit set of 'Leticia' plums.

\begin{tabular}{lccc}
\hline Treatments & $\begin{array}{c}\text { Dose of } \\
\text { commercial } \\
\text { product }\end{array}$ & $\begin{array}{c}\text { Moment of } \\
\text { application }\end{array}$ & Fruit set (\%) \\
\hline Untreated Control & - & - & $5.9 \mathrm{a}$ \\
ABA & $500 \mathrm{mg} / \mathrm{L}$ & $\mathrm{FB}$ & $3.3 \mathrm{c}$ \\
ABA + Vegetal Oil & $500 \mathrm{mg} / \mathrm{L}+3 \%$ & $\mathrm{FB}$ & $4.4 \mathrm{~b}$ \\
Benzyladenine + gibberellic acid $_{4+7}$ & $1 \mathrm{ml} / \mathrm{L}$ & $\mathrm{FB}$ & $3.5 \mathrm{C}$ \\
Benzyladenine + gibberellic acid $4+7$ & $2 \mathrm{ml} / \mathrm{L}$ & $\mathrm{FB}$ & $4.5 \mathrm{~b}$ \\
Calcium Chloride & $2 \%$ & $\mathrm{FB}$ & $2.6 \mathrm{~d}$ \\
Vegetal Oil & $3 \%$ & $\mathrm{FB}$ & $3.0 \mathrm{~d}$ \\
ABA & $250 \mathrm{mg} / \mathrm{L}$ & $15 \mathrm{DAFB}$ & $4.6 \mathrm{~b}$ \\
ABA & $500 \mathrm{mg} / \mathrm{L}$ & $15 \mathrm{DAFB}$ & $3.6 \mathrm{C}$ \\
ABA + Metamitron & $150+300 \mathrm{mg} / \mathrm{L}$ & $15 \mathrm{DAFB}$ & $5.8 \mathrm{a}$ \\
Benzyladenine & $15 \mathrm{~L} / \mathrm{ha}$ & $15 \mathrm{DAFB}$ & $2.7 \mathrm{~d}$ \\
Ethephon & $2 \mathrm{~m} / \mathrm{L}$ & $15 \mathrm{DAFB}$ & $5.3 \mathrm{a}$ \\
Metamitron & $600 \mathrm{mg} / \mathrm{L}$ & $15 \mathrm{DAFB}$ & $4.4 \mathrm{~b}$ \\
Metamitron & $500 \mathrm{mg} / \mathrm{L}$ & $15 \mathrm{DAFB}$ & $4.0 \mathrm{c}$ \\
\hline C.V. $(\%)$ & - & - & 15.81 \\
\hline
\end{tabular}

Note: Means followed by the same letters in a column are not significantly different according to the Scott-Knott test $(p<0.05)$. FB: Full Bloom; DAFB: Days After Full Bloom; ABA: Abscisic Acid.

Vegetal oil or any compound that once is in the stigmatic surface, and blocks the pollen tube development is classified as a "coating" (MYRA et al., 2007; MARCHIORETTO et al., 2019). In addition, these compounds have no effect on the pollen grain germination. For stone and pome fruits, vegetal oil at rates from 3 to $5 \%$ $\mathrm{v} / \mathrm{v}$ are effective in preventing pollination, and promote flower thinning, although when AGRARIAN ACADEMY, Centro Científico Conhecer - Goiânia, v.5, n.10; p. 772018 
applied at the proper moment, with the best results obtained when sprayed at $50 \%$ FB (JU et al., 2001). On the other hand, caustic compounds act on burning the stigmas and/or halting pollen grain germination, thus, avoiding fecundation (MYRA et al., 2007; MARCHIORETTO et al., 2018; MARCHIORETTO et al., 2019).

In this experiment, calcium chloride showed promising results for this purpose, even though no other literature is available to corroborate with our results. Similarly, for 'Golden Delicious' apples, Myra et al. (2007) found that sodium chloride indeed reduced pollen grain germination on an in vitro experiment, but in field conditions it had a mild performance in reducing fruit set, although the caustic compounds lime sulphur and ammonium thiosulfate were effective in reducing pollen grain germination, pollen tube development and on reducing fruit set. In contrast, for European plums, Pavanello et al. (2018) found no effect of ammonium thiosulfate on reducing fruit set. Although, for peaches, El-Boray et al. (2013) reported that ammonium thiosulfate at $3 \% \mathrm{v} / \mathrm{v}$ and soybean oil at $9 \% \mathrm{v} / \mathrm{v}$ reduced fruit set, and increased leaf area, indicating that somehow these treatments also stimulate vegetative growth, and maybe it causes restriction of assimilates for the flowers.

Plant growth regulators are widely used for apple fruitlet thinning, and the mechanism of action of these compounds are related in promoting fruitlet abscission (WEBSTER; SPPENCER, 2000). In general, for stone fruits, growth regulators have unreliable response when used for chemical fruitlet thinning, as they are affected by environmental factors, as well as the phenology of the tree. The stone fruits have a double-sigmoid fruitlet growth pattern, with the second peak occurring when the fruits have around $10 \mathrm{~mm}$ until the harvest. At the beginning of this phase the fruitlets are more susceptible to be abscised by the growth regulators (WEBSTER; SPENCER, 2000; GREENE, COSTA, 2013). Although, Giovanaz et al. (2015) reported that ABA was effective in promoting fruitlet thinning of 'Chirripá' peaches when sprayed at 40 DAFB in similar rates of this experiment, although, not satisfactory results were found when applied at 24 or 52 DAFB. The authors attributed the effectiveness in promoting fruitlet abscission to the ethylene buildup in the floral tissues. In this experiment, both doses of ABA were effective at FB and 15 DAFB.

The growth regulator benzyladenine and in the commercial available product, Promalin, which is associated with gibberellic acid, acts on stimulating whole tree growth at the apical meristems, creating a temporary shortage of assimilates to the fruitlets, and then inducing the abscission of part of them (YUAN; GREENE, 2000). Theron et al. (2016) found no response of benzyladenine at 100 and $300 \mathrm{ml} / \mathrm{L}$ to reduce fruit set of peaches, when the chemical was sprayed in fruitlets with $10 \mathrm{~mm}$ of diameter. In addition, Bhatt et al. (2017) found that benzyladenine at 250 or $500 \mathrm{ml} / \mathrm{L}$ had no results in decreasing blossom density in 'Kala Amritsari' Japanese plums, contrasting this experiment.

The herbicide metamitron acts inhibiting the photosynthetic rate of the plants, and ultimately it has been used in apple orchards, when the fruitlets are with 8 to 15 $\mathrm{mm}$ (GREENE; COSTA, 2013). In Israel, metamitron effectively promoted thinning of 'Gala' apples when sprayed at 6 or $10 \mathrm{~mm}$ fruitlet diameter (STERN, 2016). On the other hand, in Brazil, metamitron at $350 \mathrm{mg} / \mathrm{L}$ was effective to reduce 'Fuji' apple fruit set only when associated with benzyladenine (GABARDO et al., 2017). Although, in 'Redhaven' peaches, Turk et al. (2014) found no response of metamitron at $500 \mathrm{mg} / \mathrm{L}$ sprayed when the fruitlets had $8 \mathrm{~mm}$ of diameter. In this study, metamitron seemed to be a potential fruitlet thinner for 'Leticia' plums. Ethephon had no effect on fruit set in this experiment. This result is corroborated by Pavanello et al. (2018) where 
ethephon did not promote flower thinning and had little effect on fruit set. This growth regulator has variable results and the weather conditions have a huge influence on the performance, as when sprayed later in the season, it tends to be more effective than when used at early spring, due to the colder temperatures in the beginning of the season (WEBSTER; SPENSER, 2000).

\section{CONCLUSION}

'Leticia' Japanese plums are thinned by calcium chloride, vegetal oil, ABA, and benzyladenine + gibberellic acid ${ }_{4+7}$ when sprayed at full bloom .

Benzyladenine, $A B A$, and metamitron promote fruitlet thinning of 'Leticia' plums when sprayed at 15 days after full bloom.

\section{ACKNOWLEDGMENTS}

The authors thank CAPES for scholarship grant, and CNPq for financial support.

\section{REFERENCES}

BHATT, S.; DIMRI, D.C.; RAO, V.K.; SINGH, A.K.; PANDEY, Y.; et al. Efficacy of Blossom Thinners on Flowering, Fruit Retention and Yield Attributes in Plum (Prunus Saliciana L.) cv.'Kala Amritsari'. Chemical Science Review and Letters, v.6, n.21, p.64-68, 2017. Disponível em: <http://chesci.com/wpcontent/uploads/2017/01/V6i21_9_CS102048011_64-68.pdf>.

EL-BORAY, M. S.; SHALAN, A. M.; KHOURI, Z. M. Effect of different thinning techniques on fruit set, leaf area, yield and fruit quality parameters of Prunus persica L. Batsch cv. Floridaprince. Trends in Horticultural Research, v. 3, n. 1, p. 1-13, 2013. Disponível em: <https://scialert.net/abstract/?doi=thr.2013.1.13>. doi: 10.3923/thr.2013.1.13

EROGUL, D.; SEN, F. Effects of gibberellic acid treatments on fruit thinning and fruit quality in Japanese plum (Prunus salicina Lindl.). Scientia Horticulturae, v. 186, p. 137-142, 2015. Disponível em: <https://doi.org/10.1016/j.scienta.2015.02.019>. doi: 10.1016/j.scienta.2015.02.019

FALLAHI, E.; GREENE, D. W. The impact of blossom and postbloom thinners on fruit set and fruit quality in apples and stone fruits. In: XI International Symposium on Plant Bioregulators in Fruit Production 884. P. 179-187, 2010. Disponível em: $<$ https://doi.org/10.17660/ActaHortic.2010.884.20>.

doi:10.17660/ActaHortic.2010.884.20

FALLAHI, E.; WILLEMSEN, K.M. Blossom thinning of pome and stone fruit. HortScience, v.37, n.3, p. 474-476, 2002. Disponível em: <http://hortsci.ashspublications.org/content/33/3/553.2.short>.

FERREIRA, D.F. SISVAR - programa estatístico. Versão 5.3 (Build 75). Lavras: Universidade Federal de Lavras, 2010.

GABARDO, G.C.; PETRI, J.L.; HAWERROTH, F.J.; COUTO, M.; ARGENTA, L.C.; et al. Use of metamitron as an apple thinner. Revista Brasileira de Fruticultura, v. 39, 
n. 3, 2017. Disponível em: <http://dx.doi.org/10.1590/0100-29452017514>. doi: $10.1590 / 0100-29452017514$

GIOVANAZ, M.A.; SPAGNOL, D.; BARTZ, J.; PASA, M.S.; CHAVES, F.C.; et al. Abscisic acid as a potential chemical thinner for peach. Pesquisa Agropecuária Brasileira, v. 50, n. 10, p. 989-992, 2015. Disponível em: <http://dx.doi.org/10.1590/S0100-204X2015001000015>. doi: 10.1590/S0100204X2015001000015

GREENE, D.; COSTA, G. Fruit thinning in pome-and stone-fruit: state of the art. In: EUFRIN Thinning Working Group Symposia 998. p. 93-102, 2013. Disponível em: <https://doi.org/10.17660/ActaHortic.2013.998.10>. doi: 10.17660/ActaHortic.2013.998.10

JU, Z.; DUAN, Y.; JU, Z.; GUO, A. Corn oil emulsion for early bloom thinning of trees of 'Delicious' apple, 'Feng Huang' peach, and 'Bing' cherry. The Journal of Horticultural Science and Biotechnology, v. 76, n. 3, p. 327-331, 2001. Disponível em: $\quad$ <https://doi.org/10.1080/14620316.2001.11511371>. doi: 10.1080/14620316.2001.11511371

LAKSO, A.N.; GOFFINET, M. Apple fruit growth. New York Quarterly, v.21, n.1, p.11-14, 2013. Disponível em: <http://www.hort.cornell.edu/expo/proceedings/2014/Tree\%20Fruit/Apple\%20Fruit\%2 0Growth\%20Lakso.pdf>.

LENAHAN, O.M.; WHITING, M.D. Physiological and horticultural effects of sweet cherry chemical blossom thinners. HortScience, v. 41, n. 7, p. 1547-1551, 2006. Disponível em: <http://hortsci.ashspublications.org/content/41/7/1547.short>.

MARCHIORETTO, L.R.; DE ROSSI, A.; MICHELON, M.F.; ORLANDI, J.C.; AMARAL, L.O. Ammonium thiosulfate as blossom thinner in 'Maxi Gala' apple trees. Pesquisa Agropecuária Brasileira, v.53, n.10, p.1132-1139, 2018. Disponível em: <http://dx.doi.org/10.1590/s0100-204×2018001000006>. doi: 10.1590/S0100204X2018001000006

MARCHIORETTO, L.R.; DE ROSSI, A.; AMARAL, L.O.; RIBEIRO, A.M.A.S. Efficacy and mode of action of blossom thinners on 'Fuji More' apple trees. Scientia Horticulturae, v.246, p.634-642, 2019. Disponível em: <https://doi.org/10.1016/j.scienta.2018.11.039>. doi: 10.1016/j.scienta.2018.11.039

McARTNEY, S.; PALMER, J.; DAVIES, S.; SEYMOUR, S. Effects of lime sulphur and fish oil on pollen tube growth, leaf photosynthesis and fruit set in apple. HortScience, v.41, n.2, p.357-360, $2006 . \quad$ Disponível em: $<$ http://hortsci.ashspublications.org/content/41/2/357.short>.

MEITEI, S.B.; PATEL, R.K.; DEKA, B.C.; DESHMUKH, N.A.; SINGH, A. Effect of chemical thinning on yield and quality of peach cv. Flordasun. African Journal of Agricultural Research, v. 8, n. 27, p. 3558-3565, 2013. Disponível em: $<$ http://dx.doi.org/10.5897/AJAR2013.7058>. doi: 10.5897/AJAR2013.7058 
MYRA, M.T; EMBREE, C.G.; GOOD-AVILA, S.V.; MORTON, V.K. Assessment of potential organic pollenicides as apple blossom thinners. International journal of fruit science, $\quad$ v. $6, \quad$ n. $3, \quad$ p. 35-52, 2007. Disponível em: <https://doi.org/10.1300/J492v06n03_04>.doi: 10.1300/J492v06n03_04

PAVANELLO, A.P.; ZOTH, M.; AYUB, R.A. Manage of crop load to improve fruit quality in plums. Revista Brasileira de Fruticultura, v. 40, n. 4, 2018. Disponível em: <http://dx.doi.org/10.1590/0100-29452018721>. doi: 10.1590/010029452018721

STERN, R.A. The photosynthesis inhibitor Metamitron is an effective fruitlet thinner for 'Gala' apple in the warm climate of Israel. In: XXIX International Horticultural Congress on Horticulture: Sustaining Lives, Livelihoods and Landscapes (IHC2014): $1119 . \quad$ p. 15-24, 2014. Disponível em: <https://doi.org/10.17660/ActaHortic.2016.1119.2>. doi: 10.17660/ActaHortic.2016.1119.2

THERON, K. I.; STEENKAMP, H.; LÖTZE, G.F.A.; STEYN, W.J. The efficacy of chemical and mechanical thinning strategies for 'African Rose' Japanese plum (Prunus salacina Lindl.). In: EUFRIN Thinning Working Group Symposia 1138. p. 61-68, 2016. Disponível em: <https://doi.org/10.17660/ActaHortic.2016.1138.8>. doi: 10.17660/ActaHortic.2016.1138.8

TURK, B.A.; FAJT, N.; STOPAR, M. Tergitol as a possible thinning agent for peach cv. Redhaven. Horticultural Science, v. 41, n. 2, p. 49-54, 2014. Disponível em: $<$ https://www.agriculturejournals.cz/publicFiles/124184.pdf>.

WEBSTER, A.D.; SPENCER, J.E. Fruit thinning plums and apricots. Plant Growth Regulation, v.31, p.101-112, $2000 . \quad$ Disponível em: <https://doi.org/10.1023/A:1006335620972>. doi: 10.1023/A:1006335620972

YUAN, R.; GREENE, D.W. Benzyladenine as A Chemical Thinner for 'Mclntosh' Apples. I. Fruit Thinning Effects and Associated Relationships with Photosynthesis, Assimilate Translocation, and Nonstructural Carbohydrates. Journal of the American Society for Horticultural Science, v. 125, n. 2, p. 169-176, 2000. Disponível em: <http://journal.ashspublications.org/content/125/2/169.short>. 